\title{
Characterization of Austenitic Stainless Steels Deformed at Elevated Temperature
}

\author{
MATTIAS CALMUNGER, GUOCAI CHAI, ROBERT ERIKSSON, \\ STEN JOHANSSON, and JOHAN J. MOVERARE
}

\begin{abstract}
Highly alloyed austenitic stainless steels are promising candidates to replace more expensive nickel-based alloys within the energy-producing industry. The present study investigates the deformation mechanisms by microstructural characterization, mechanical properties and stress-strain response of three commercial austenitic stainless steels and two commercial nickel-based alloys using uniaxial tensile tests at elevated temperatures from $673 \mathrm{~K}\left(400{ }^{\circ} \mathrm{C}\right)$ up to $973 \mathrm{~K}\left(700{ }^{\circ} \mathrm{C}\right)$. The materials showed different ductility at elevated temperatures which increased with increasing nickel content. The dominating deformation mechanism was planar dislocation-driven deformation at elevated temperature. Deformation twinning was also a noticeable active deformation mechanism in the heat-resistant austenitic alloys during tensile deformation at elevated temperatures up to $973 \mathrm{~K}\left(700^{\circ} \mathrm{C}\right)$.
\end{abstract}

DOI: $10.1007 / \mathrm{s} 11661-017-4212-9$

(C) The Author(s) 2017. This article is an open access publication

\section{INTRODUCTION}

FOR sustainable energy production, renewable energy resources with high efficiency are needed. ${ }^{[1-3]}$ One way to achieve a higher efficiency in sustainable energy production is to increase the temperature and pressure in the boiler section ${ }^{[4]}$ of, for instance, biomass-fuelled power plants. ${ }^{[1]}$

Higher temperature and pressure will increase the demand for improved high-temperature properties of the materials that operate in high-efficiency power plants. For the components in the boiler section, resistance to fireside corrosion and steamside oxidation, creep-rupture strength and fabricability are the most important material requirements. ${ }^{[1,4-6]}$ Austenitic stainless steels are commonly used for components within the energy-producing industry ${ }^{[1,4-6]}$ due to their high corrosion resistance, good creep resistance and excellent ductility, formability and toughness. ${ }^{[6-8]}$ Advanced austenitic stainless steels are designed to withstand temperatures up to $923 \mathrm{~K}\left(650^{\circ} \mathrm{C}\right)$ or even $973 \mathrm{~K}\left(700{ }^{\circ} \mathrm{C}\right)$.

MATTIAS CALMUNGER, STEN JOHANSSON, and JOHAN J. MOVERARE are with the Division of Engineering Materials, Department of Management and Engineering, Linköping University, 58183 Linköping, Sweden. Contact e-mail: mattias.calmunger@liu.se GUOCAI CHAI is with the Division of Engineering Materials, Department of Management and Engineering, Linköping University, and also with the AB Sandvik Materials Technology R\&D Center, 81181 Sandviken, Sweden. ROBERT ERIKSSON is with the Division of Solid Mechanics, Department of Management and Engineering, Linköping University, 58183 Linköping, Sweden.

Manuscript submitted September 30, 2016.

Article published online July 17, 2017
At higher temperatures, the recovery phenomena of dynamic recrystallization (DRX) occurs. DRX is associated with recrystallized grains in the microstructure. ${ }^{[9]}$ At higher temperatures, $973 \mathrm{~K}\left(700^{\circ} \mathrm{C}\right)$ and above, nickel-based superalloys are often used. ${ }^{[4]}$

It has been reported that mechanical properties, like strength, may be significantly changed due to dynamic strain aging (DSA). ${ }^{[10,11]}$ DSA can lead to an increase in flow stress and strain hardening rate. ${ }^{[12,13]}$ Austenitic stainless steels show DSA in a temperature range from 473 $\mathrm{K}$ to $1073 \mathrm{~K}\left(200^{\circ} \mathrm{C}\right.$ to $\left.800^{\circ} \mathrm{C}\right),{ }^{[14-16]}$ which includes both the operating temperatures of today's power plants and the elevated operating temperatures for future power plants. ${ }^{[5]}$ DSA originates from interaction between solute atoms and dislocations during plastic deformation. Under plastic flow, dislocations are gliding until they come across an obstacle where they are stationary until the obstacles are surmounted. When the dislocations are stationary, solute atoms can diffuse towards the dislocations which results in an increase in the activation energy for further slip and, consequently, also an increase in the stress needed for overcoming the obstacle..$^{[15,17-20]}$ At temperatures below $623 \mathrm{~K}\left(350{ }^{\circ} \mathrm{C}\right)$, carbon is proposed to be responsible for DSA while nitrogen and/or substitutional chromium atoms are proposed to be responsible at higher temperatures above $673 \mathrm{~K}\left(400{ }^{\circ} \mathrm{C}\right) \cdot{ }^{[10,21]} \mathrm{DSA}$ is characterized by serrated yielding in the stress-strain curve, denoted as Portevin-Le Châtelier (PLC) effect or jerky flow. The PLC effect is caused by the pinning and unpinning of dislocations. ${ }^{[13,16,22,23]}$ There are different types of PLC effects, designated A to $D^{[13,16,23]}$ Type A is considered as locking serrations which abruptly rise and then drop to a stress level below the general level. Type B is 
characterized by small oscillations around the general level of the curve. Type $\mathrm{C}$ leads to unlocking serration which is when the curve abruptly drops below the general stress level. Type D is characterized by plateaus on the curve. ${ }^{[23]}$ Serrated yielding may also come from other mechanisms, e.g. deformation-induced twinning. ${ }^{[24]}$

Austenitic stainless steels are more cost-effective than nickel-based alloys due to a lower amount of expensive alloying elements. Recently, advanced, highly alloyed, heat-resistant austenitic stainless steels have been developed, such as Sandvik Sanicro ${ }^{\mathrm{TM}} 25$ (Sanicro 25). ${ }^{[25]}$ These alloys have improved high-temperature properties, for instance, creep strength, compared to other austenitic stainless steels used for high-temperature applications. However, the influence of temperature on deformation mechanisms and mechanical properties is not yet fully understood for these relatively new high-temperature-resistant austenitic stainless steels.

This study focuses on the deformation mechanisms at elevated temperatures for three commercial austenitic stainless steels and two commercial nickel-based alloys. The alloys were characterized in terms of microstructure, mechanical properties and stress-strain response. The alloys cover a range from relatively low alloyed austenitic stainless steel (e.g. AISI 316L) to nickel-based alloys (e.g. Alloy 617) and the interesting area between austenitic stainless steels and nickel-based alloys consisting of the advanced, highly alloyed, heat-resistant austenitic stainless steel Sanicro 25. The different austenitic alloys were tested by uniaxial tensile testing at different elevated temperatures from $673 \mathrm{~K}\left(400{ }^{\circ} \mathrm{C}\right)$ up to $973 \mathrm{~K}\left(700{ }^{\circ} \mathrm{C}\right)$. Their stress-strain response was analyzed and the deformation mechanisms were characterized by scanning electron microscopy (SEM).

\section{MATERIALS AND EXPERIMENTAL PROCEDURES}

\section{A. Materials}

Three commercial austenitic stainless steels, Sanicro 25, AISI 310 and AISI 316L, and two commercial nickel-based alloys, Alloy 617 and Alloy 800HT, were used in this study. Table I lists the chemical composition. All five materials were supplied by AB Sandvik Materials Technology. The alloys were solution heattreated, according to Table II, before the specimens were cut. Figure 1 displays the microstructures of Alloy
617 and Sanicro 25 in as-received condition; the nickel-based alloy had larger grains than the stainless steel and both microstructures contained annealing twins formed during the manufacturing process.

\section{B. Mechanical Test Procedure}

Uniaxial tensile tests were performed to obtain the stress-strain response. Ductility, yield and tensile strength values were taken from engineering stressstrain curves. Strain hardening rate values and plastic strain were obtained from true stress-strain curves that were calculated from the engineering stress and strain values. For the tensile testing, a Roell-Korthaus tensile test machine equipped with a MTS 653 furnace and a Magtec PMA-12/2/VV7-1 extensometer was used. All the tensile tests were performed according to the standard EN 10 002-1. Round bar specimens, $5 \mathrm{~mm}$ in diameter and 50-mm gauge length, were used. The tensile tests were carried out using a strain rate of $2 \times 10^{-3} \mathrm{~s}^{-1}$. Six temperatures were tested: $296 \mathrm{~K}(23$ $\left.{ }^{\circ} \mathrm{C}\right)$, i.e. room temperature (RT), as a reference, and 673 $\mathrm{K}, 773 \mathrm{~K}, 873 \mathrm{~K}, 923 \mathrm{~K}$ and $973 \mathrm{~K}\left(400{ }^{\circ} \mathrm{C}, 500{ }^{\circ} \mathrm{C}, 600\right.$ ${ }^{\circ} \mathrm{C}, 650{ }^{\circ} \mathrm{C}$ and $700{ }^{\circ} \mathrm{C}$ ).

\section{Microstructural Analysis by Scanning Electron Microscopy}

The SEM techniques electron channelling contrast imaging (ECCI) and electron backscatter diffraction (EBSD) were used to characterize the deformed microstructure. All microstructural analyses were conducted after failure or in as-received condition. Before the investigation, the cross-sections parallel to the deformation axis of the specimens were cut, using an

Table II. Solution Heat Treatment of the Austenitic Materials

\begin{tabular}{lcc}
\hline Alloy & Temperature $/ \mathrm{K}\left({ }^{\circ} \mathrm{C}\right)$ & Time $/ \mathrm{min}$ \\
\hline Sanicro 25 & $1523(1250)$ & 10 \\
AISI 310 & $1323(1050)$ & 10 \\
AISI 316L & $1323(1050)$ & 10 \\
Alloy 800HT & $1473(1200)$ & 15 \\
Alloy 617 & $1448(1175)$ & 20 \\
\hline
\end{tabular}

Table I. Nominal Composition of the Austenitic Materials in Weight Percent

\begin{tabular}{lcccccccccccc}
\hline Alloy & $\mathrm{C}$ & $\mathrm{Si}$ & $\mathrm{Mn}$ & $\mathrm{Cr}$ & $\mathrm{Ni}$ & $\mathrm{Mo}$ & $\mathrm{Cu}$ & $\mathrm{W}$ & $\mathrm{Co}$ & $\mathrm{Nb}$ & $\mathrm{N}$ & $\mathrm{Fe}$ \\
\hline Sanicro 25 & 0.067 & 0.25 & 0.47 & 22.33 & 24.91 & 0.24 & 2.95 & 3.37 & 1.44 & 0.52 & 0.236 & $*$ \\
AISI 310 & 0.046 & 0.55 & 0.84 & 25.43 & 19.21 & 0.11 & 0.08 & - & - & - & 0.04 & $*$ \\
AISI 316L & 0.04 & 0.4 & 1.7 & 17.0 & 12.0 & 2.6 & - & - & - & - & - & $*$ \\
Alloy 800HT & 0.063 & 0.71 & 0.5 & 20.32 & 30.06 & $\mathrm{Al} / 0.5$ & $\mathrm{Ti} / 0.5$ & - & - & - & - & $*$ \\
Alloy 617 & 0.061 & - & - & 22.53 & 53.8 & 9.0 & $\mathrm{Al} / 0.9$ & - & 12.0 & - & - \\
\hline
\end{tabular}

*Balance. 

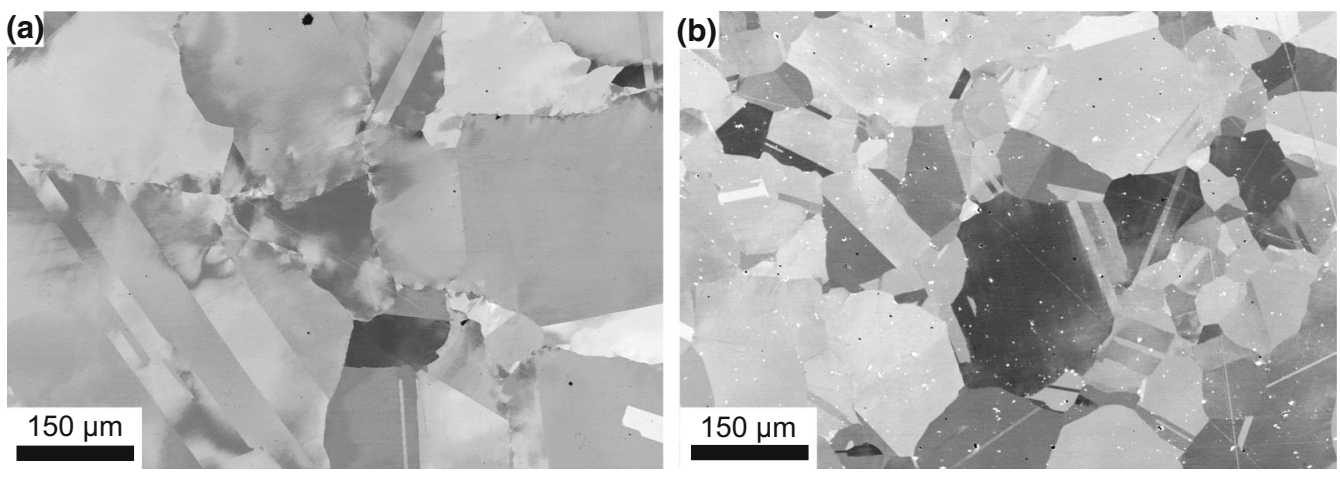

Fig. 1-As-received microstructure of Alloy 617 (a) and Sanicro $25(b)$.

electric discharge wire to minimise the effects of surface hardening. The specimens were then carefully mechanically ground and polished according to the procedure in Reference 26. Three areas in the microstructure were used to characterize the deformation using ECCI. The locations were approximately $0.6,6.0$ and $12.0 \mathrm{~mm}$ from the fracture surface and equal in width to the specimen's diameter.

ECCI is a powerful SEM technique to image deformation, damage and even dislocation and twin structures in highly deformed alloys by using backscattered electrons. ECCI uses the interaction between backscattered electrons and the crystal planes to generate contrast, resulting in an image where local misorientation, defects and strain fields are shown as contrast variations. ${ }^{[27,28]}$ For the ECCI observations, a Zeiss Crossbeam instrument (XB 1540, Carl Zeiss SMT AG, Germany) was used, consisting of a Gemini type field emission gun (FEG) electron column. ECCI was performed at 10-kV acceleration voltages and a working distance of $5 \mathrm{~mm}$, using a solid-state four-quadrant BSD detector.

The EBSD technique was used to analyse the twin structure. EBSD was performed in a HITACHI SU-70 FEG-SEM equipped with an OXFORD EBSD detector. EBSD maps were measured at $15-\mathrm{kV}$ acceleration voltage and a working distance of $25 \mathrm{~mm}$ and the EBSD maps were produced using a step size of $0.1 \mu \mathrm{m}$. The HKL software CHANNEL 5 was used for the microstructure evaluation.

\section{RESULTS}

\section{A. Mechanical Response}

The engineering stress-strain curves at all tested temperatures are shown in Figures 2 and 3, and summarise some of the derived material parameters as a function of temperature. As seen in Figure 3, all materials exhibited decreasing yield strength $(0.2$ pct proof stress), as well as tensile strength, with increasing temperature.

The temperature dependence of ductility (strain to rapture), however, was different for the studied materials. Three different ductility responses could be distinguished, as seen in Figure 3(c). AISI 316L and AISI 310 showed decreasing ductility with increasing temperature compared with RT. Sanicro 25 and Alloy $800 \mathrm{HT}$ had ductilities that initially increased until reaching $973 \mathrm{~K}$ and $923 \mathrm{~K}\left(700{ }^{\circ} \mathrm{C}\right.$ and $\left.650{ }^{\circ} \mathrm{C}\right)$, respectively, where they dropped compared to $\mathrm{RT}$. Alloy 617 showed a ductility at elevated temperatures that was higher compared with RT.

Figure 3(d) displays the strain hardening rates for all alloys (taken as the mean strain hardening rate in the 5to 15 -pct plastic strain interval). Some differences in hardening behavior between the materials were observed. The lower-alloyed stainless steels, AISI $316 \mathrm{~L}$ and AISI 310, showed a rapid decrease in the strain hardening rate as the temperature exceeded $873 \mathrm{~K}(600$ $\left.{ }^{\circ} \mathrm{C}\right)$. The more highly alloyed stainless steel, Sanicro 25, and the nickel-based alloys showed a relatively linearly decreasing strain hardening rate with increasing temperature. At $973 \mathrm{~K}\left(700{ }^{\circ} \mathrm{C}\right)$, Sanicro 25 showed a sudden increase in strain hardening rate.

Additionally, serrated yielding was observed in all materials at all or some of the elevated temperatures, as seen in Figure 2. A certain dependence on chemical composition was observed. The comparably low-alloyed stainless steels, AISI $316 \mathrm{~L}$ and AISI 310, showed serrated yielding from $873 \mathrm{~K}$ to $973 \mathrm{~K}\left(600{ }^{\circ} \mathrm{C}\right.$ to 700 ${ }^{\circ} \mathrm{C}$ ), shown for AISI 316L in Figures 4(a) through (c). The more highly alloyed stainless steel, Sanicro 25, showed mild serrated yielding at $773 \mathrm{~K}$ and $873 \mathrm{~K}$ (500 ${ }^{\circ} \mathrm{C}$ and $600{ }^{\circ} \mathrm{C}$ ) and more pronounced serrated yielding at $923 \mathrm{~K}$ and $973 \mathrm{~K}\left(650{ }^{\circ} \mathrm{C}\right.$ and $\left.700{ }^{\circ} \mathrm{C}\right)$, shown in Figures 4(d) through (f). The nickel-based alloys showed serrated yielding at all tested elevated temperatures, as seen for Alloy 617 in Figures 4(g) through (i). The serrated yielding can be described by the different PLC types related to DSA. AISI 316L showed PLC type $\mathrm{A}, \mathrm{A}$ and $\mathrm{B}+\mathrm{C}$ and AISI 310 showed PLC type A, A and $\mathrm{A}+\mathrm{B}$ for $873 \mathrm{~K}, 923 \mathrm{~K}$, and $973 \mathrm{~K}\left(600{ }^{\circ} \mathrm{C}, 650^{\circ} \mathrm{C}\right.$, and $700{ }^{\circ} \mathrm{C}$ ), respectively. Sanicro 25 showed PLC type C, C, A and C for $773 \mathrm{~K}, 873 \mathrm{~K}, 923 \mathrm{~K}$, and $973 \mathrm{~K}(500$ ${ }^{\circ} \mathrm{C}, 600{ }^{\circ} \mathrm{C}, 650{ }^{\circ} \mathrm{C}$, and $700{ }^{\circ} \mathrm{C}$ ), respectively. Alloy 617 showed PLC type B, B, B, B and $\mathrm{B}+\mathrm{C}$ and Alloy $800 \mathrm{HT}$ showed PLC type A+B, A+B, B, B and B+C for $673 \mathrm{~K}\left(400{ }^{\circ} \mathrm{C}\right), 773 \mathrm{~K}, 873 \mathrm{~K}, 923 \mathrm{~K}$, and $973 \mathrm{~K}(500$ ${ }^{\circ} \mathrm{C}, 600{ }^{\circ} \mathrm{C}, 650{ }^{\circ} \mathrm{C}$, and $700{ }^{\circ} \mathrm{C}$ ), respectively. 


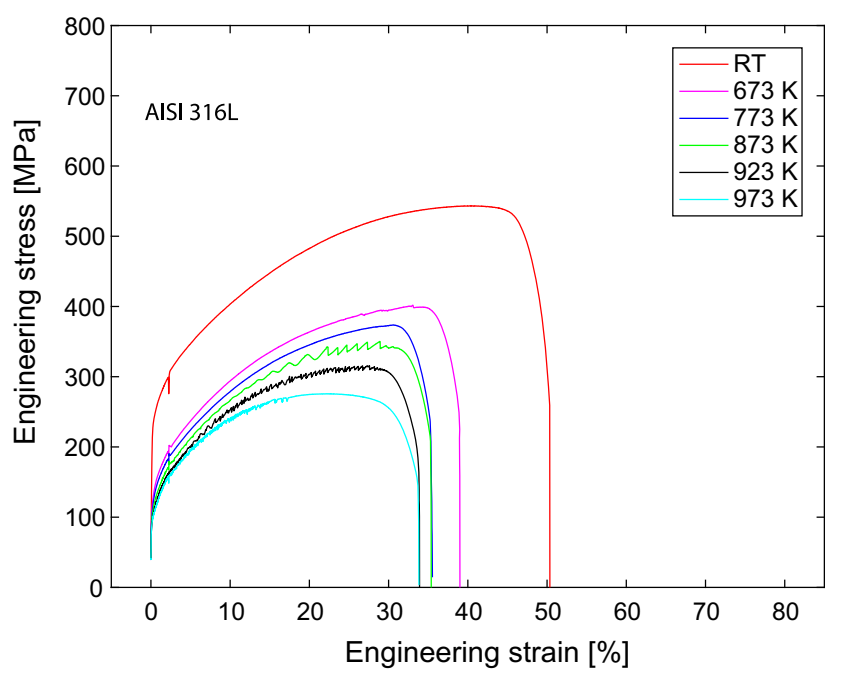

(a)

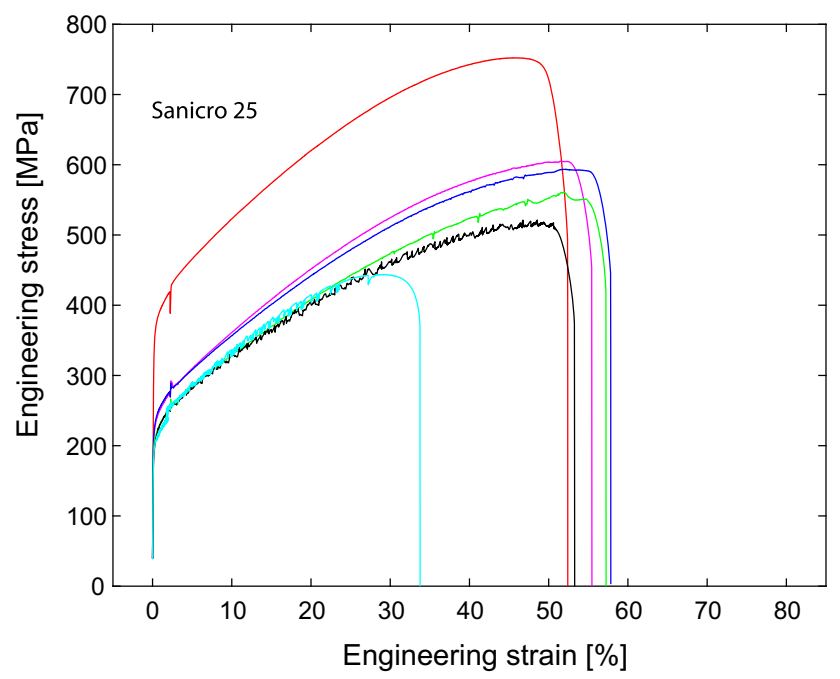

(c)

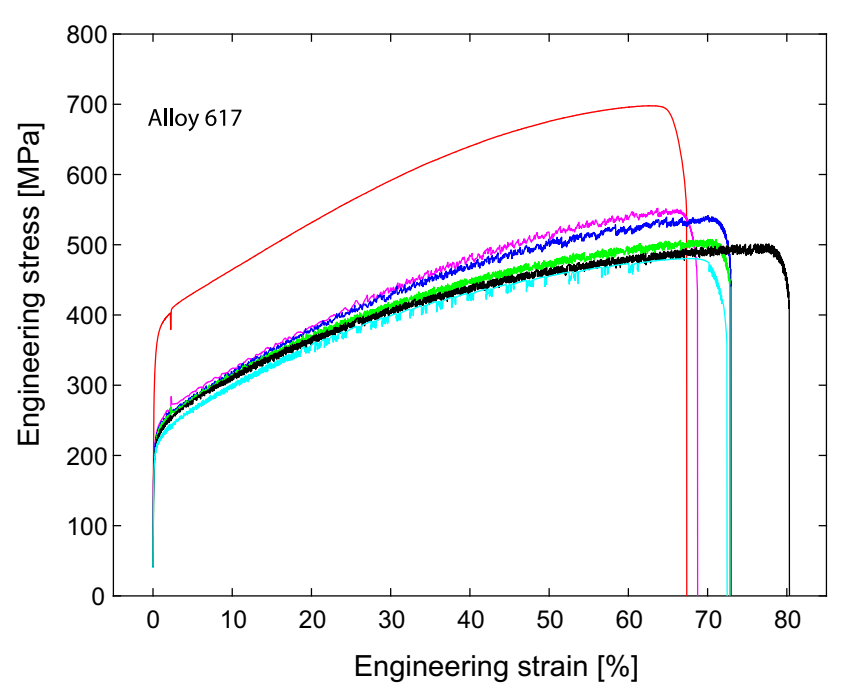

(e)

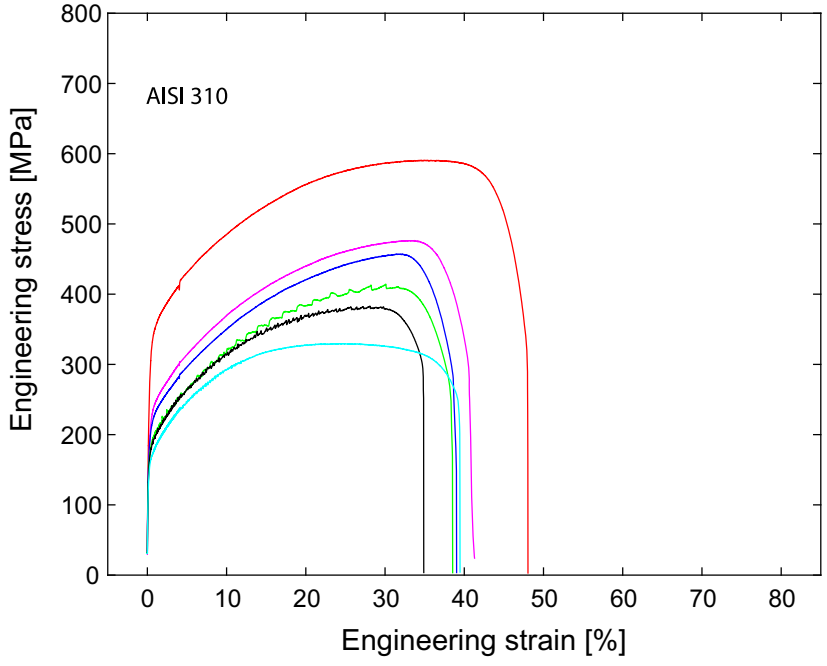

(b)

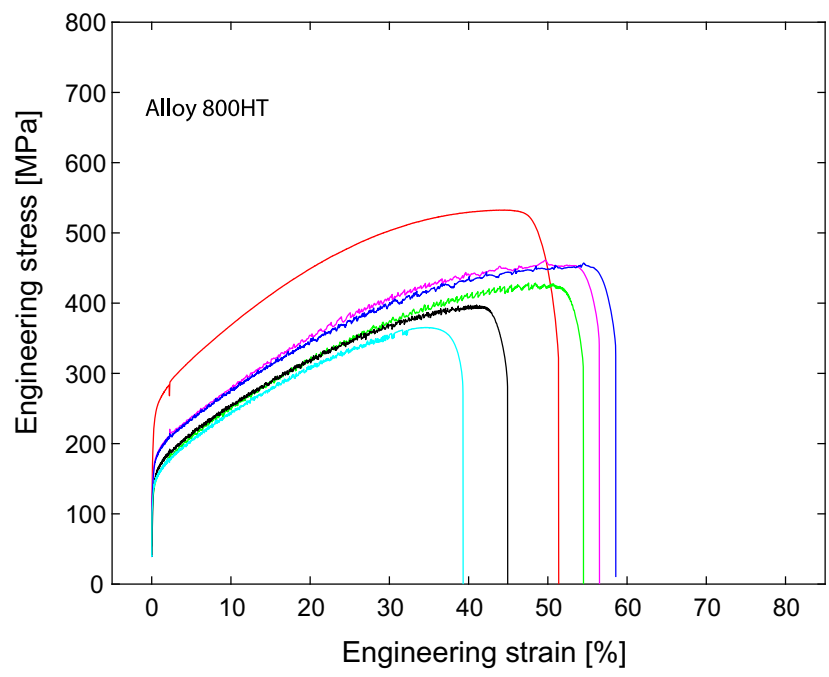

(d)

Fig. 2-Engineering stress-strain curves for all materials at all tested temperatures of AISI 316L (a), AISI 310 (b), Sanicro 25 (c), Alloy $800 \mathrm{HT}$ (d) and Alloy 617 (e). Same legend as in (a) for all curves. 


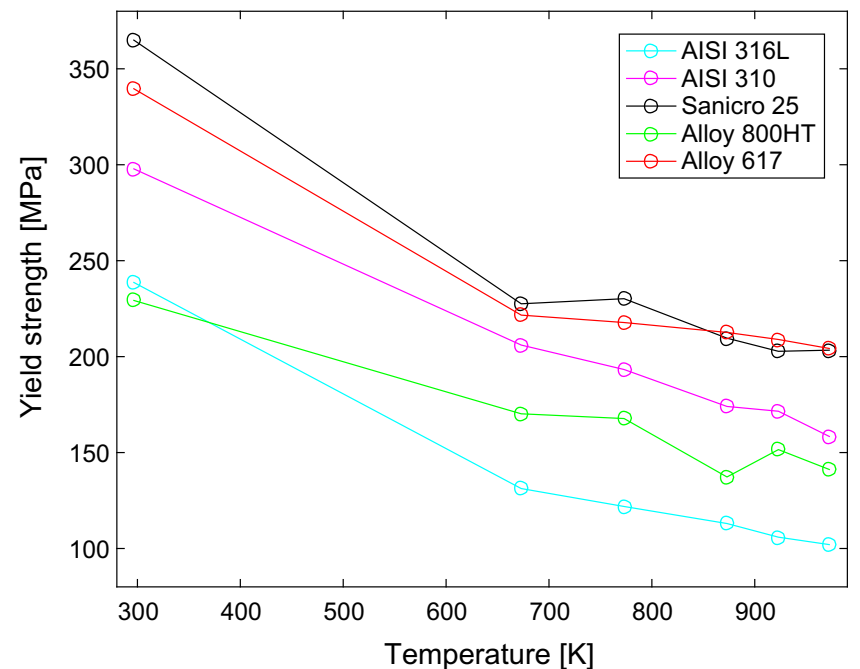

(a)

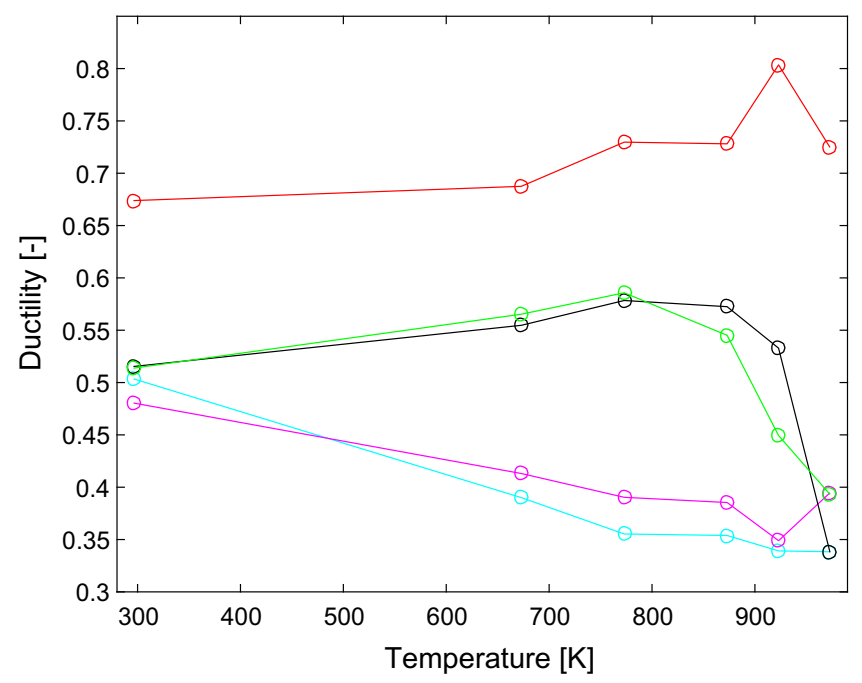

(c)

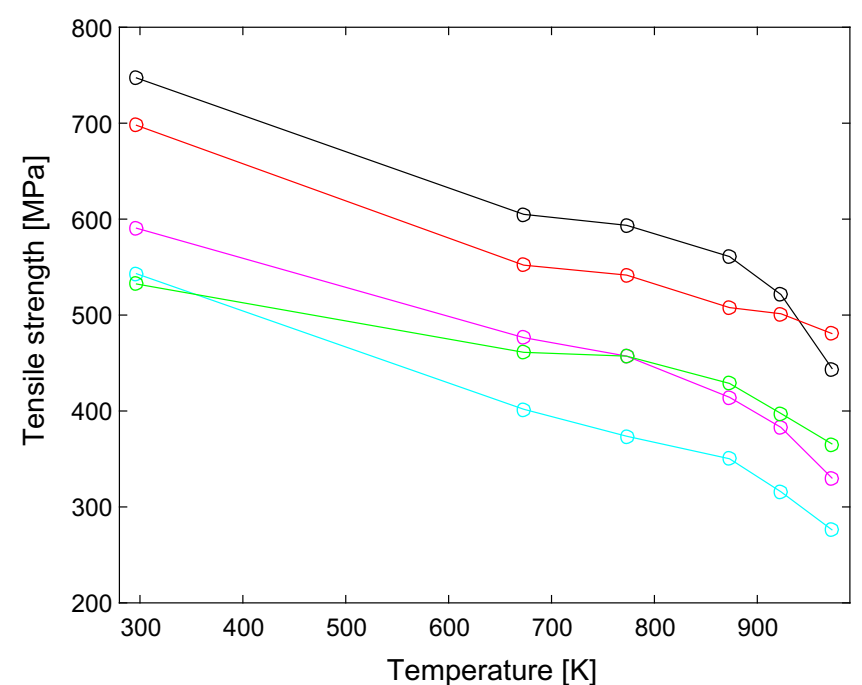

(b)

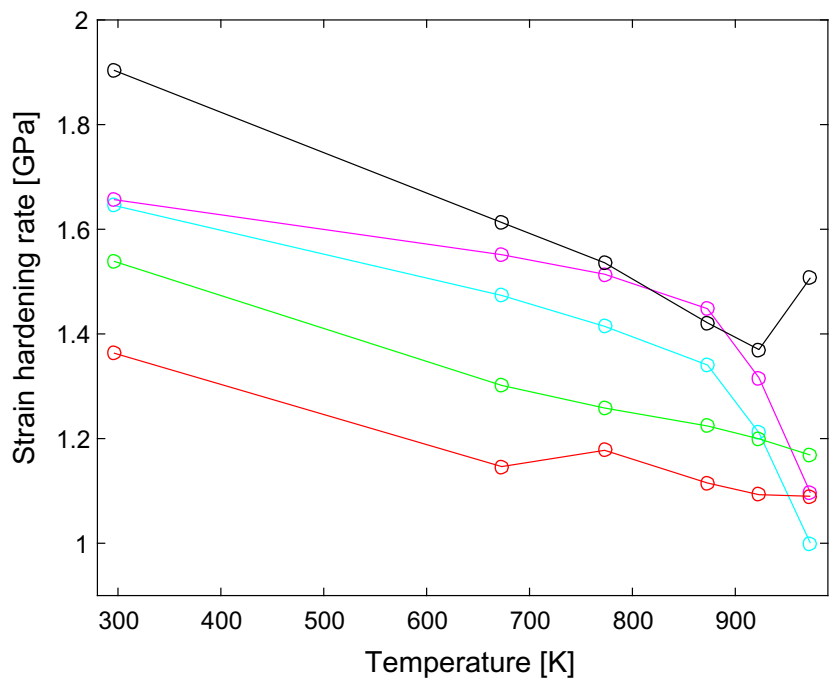

(d)

Fig. 3-Mechanical properties for all materials at elevated temperatures: yield strength $(0.2$ pct proof stress; $a)$, tensile strength $(b)$, ductility $(c)$ and strain hardening rate, 5 to 15 pct plastic strain, $(d)$. Same legend as in (a) for all curves.

\section{B. Deformation Mechanisms in Austenitic Stainless Steels and Nickel-Based Alloys}

At room temperature, deformation mechanisms such as planar slip, slip bands and deformation twins were active and could be observed in the microstructure, as shown in Figure 5. The deformation behavior was similar for all materials. Close to the fracture surface, all materials showed severe plastic deformation involving multi-directional slipping as well as twinning. All materials exhibited a ductile fracture surface, as shown for Sanicro 25 in Figure 6(a). The ductile character of the fracture also persisted at elevated temperatures, as seen in Figure 6(b) for Sanicro 25 at $873 \mathrm{~K}\left(600{ }^{\circ} \mathrm{C}\right)$.

At elevated temperatures, although the main deformation mechanisms were the same as at room temperature, certain differences could be observed between the different alloys and testing temperatures. Deformation twins were found in the studied materials, despite deformation twinning being unusual in austenitic stainless steels at temperatures above 0.2 times the absolute melting temperature. ${ }^{[24,29]}$ The investigated materials, except AISI 316L, however, showed deformation twinning at elevated temperature both in single and multiple directions; Figures 7 through 10 show deformation twins in AISI 310, Sanicro 25, Alloy 800HT and Alloy 617. Figure 7 show deformation twins at $923 \mathrm{~K}\left(650^{\circ} \mathrm{C}\right)$ for all alloys where deformation twinning was active at elevated temperature. By using EBSD, a deformation twin in Alloy 617 at $923 \mathrm{~K}\left(650{ }^{\circ} \mathrm{C}\right)$ was detected in Figure 8; an angular difference of 60 deg indicates twin boundaries. Figure 9 show deformation twins at RT and up to $873 \mathrm{~K}\left(600{ }^{\circ} \mathrm{C}\right)$ in AISI 310 . Figure 10 show deformation twins at RT and $923 \mathrm{~K}\left(650^{\circ} \mathrm{C}\right)$ in Sanicro 25 and Alloy 617. 


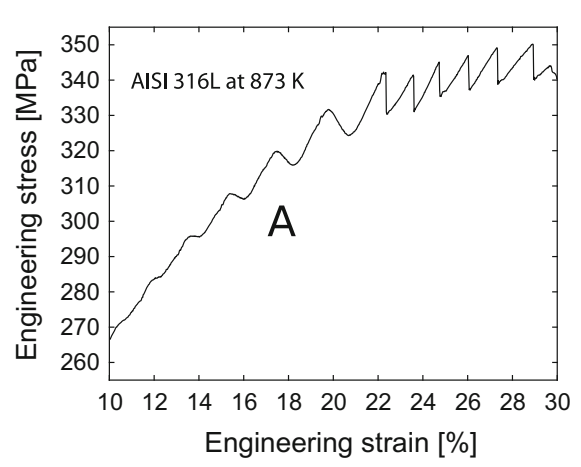

(a)

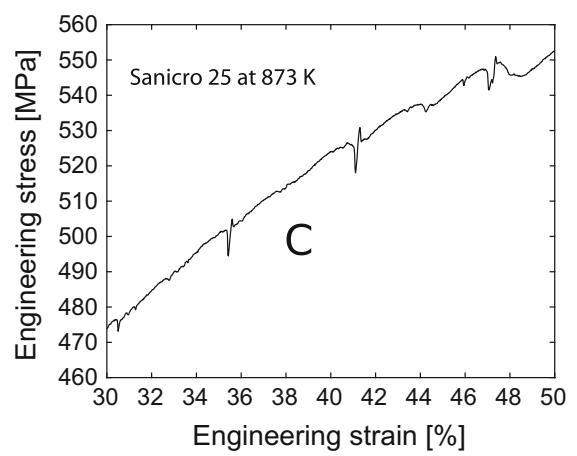

(d)

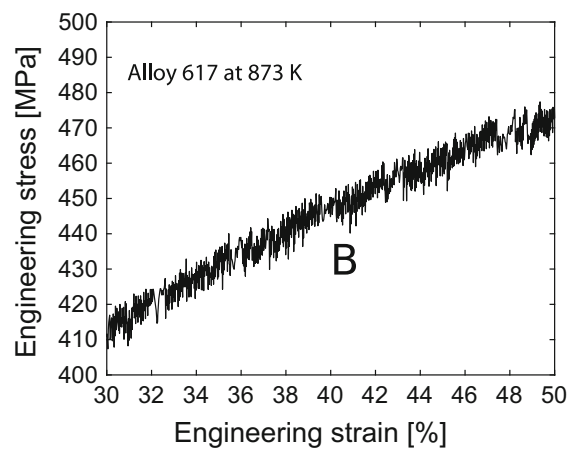

(g)

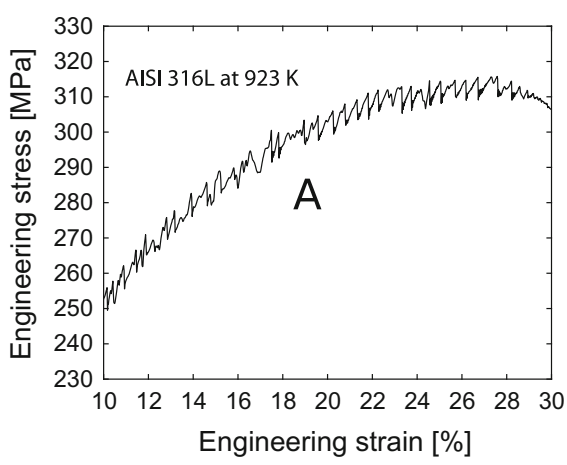

(b)

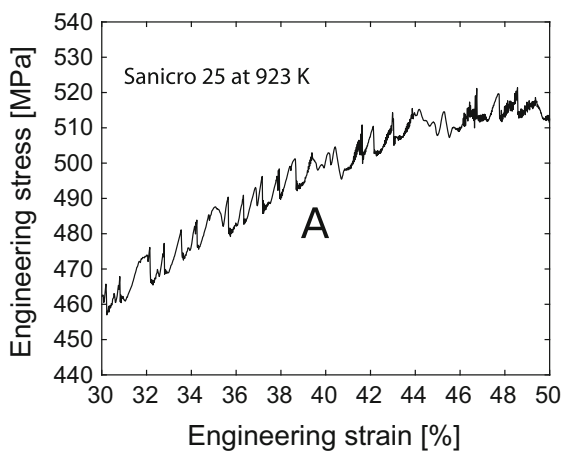

(e)

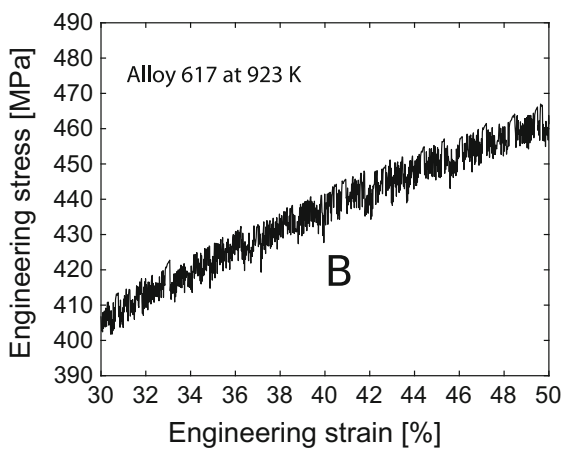

(h)

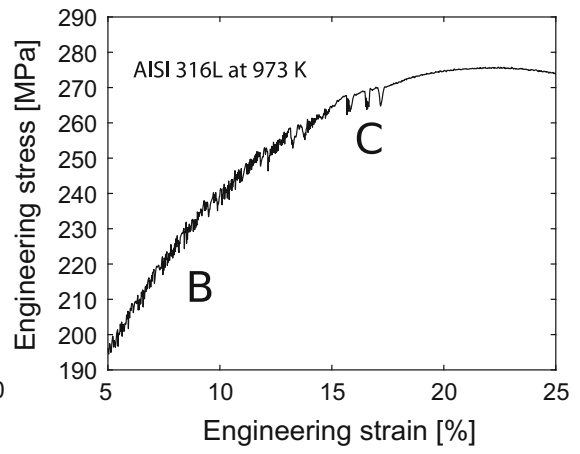

(c)

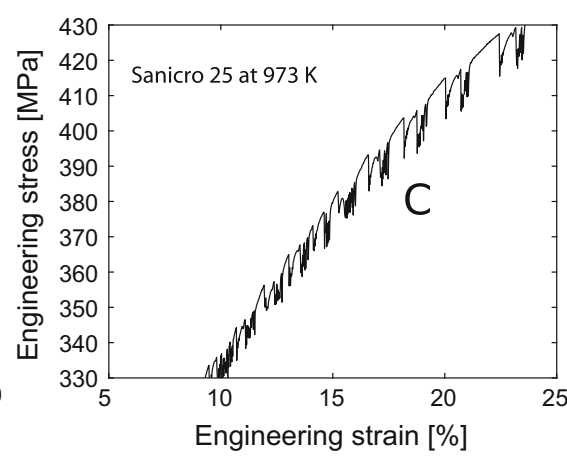

(f)

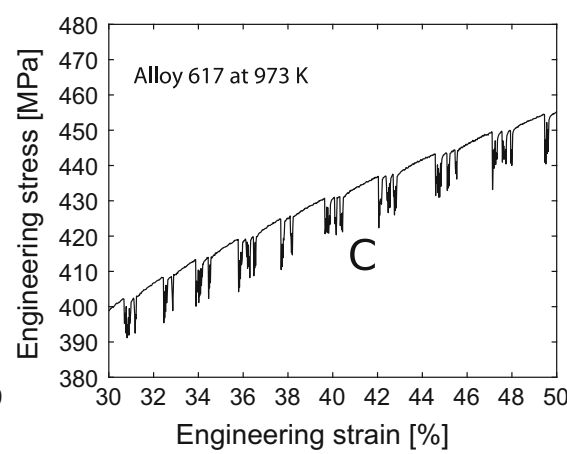

(i)

Fig. 4 - Serrated yielding and PLC-type in engineering stress-strain curves at elevated temperatures $\left[873 \mathrm{~K}, 923 \mathrm{~K}\right.$, and $973 \mathrm{~K}\left(600{ }^{\circ} \mathrm{C}, 650{ }^{\circ} \mathrm{C}\right.$, and $\left.700{ }^{\circ} \mathrm{C}\right)$ ] of AISI 316L $(a-c)$, Sanicro $25(d-f)$ and Alloy $617(g-i)$.

At the higher of the studied temperatures, recovery mechanisms, such as dynamic recrystallization (DRX), became more dominant in the lower-alloyed stainless steel AISI 316L. It showed subgrains as an early stage of DRX and recrystallized grains at grain boundaries, as shown in Figure 11. Figures 11(a) and (b) are ECCI micrographs showing DRX structures at or near grain boundaries. Figure 11(c) is an overveiw SEM micrograph in secondary electron mode showing grain boundaries with precipitates and the area which was EBSD-analyzed. Figure 11(d) shows an EBSD map displaying the Euler angles and the black lines corresponds to grain boundaries larger than $3 \mathrm{deg}$. Figure 11(d) shows that recrystallized grains have been formed at the original grain boundaries, which are marked in Figure 11(c).
The main mechanisms contributing to material damage from local stress or strain intensity, were large deformation bands and/or slip bands creating local damage when intersecting with other deformation/slip bands or with grain boundaries. The deformation bands seemed to contain bundles of slip bands or shear bands; Figure 12(a) shows such deformation in Sanicro 25. Interactions between grain boundaries and planar slip have been observed to create severe plastic deformation zones, as shown in Figure 12(b) for Alloy 617, generating a local, severely plastically deformed microstructure. The small deformation twins generated micro-damage of localised strain offsets where twins interacted with each other, as shown in Figures 12(c) and $(\mathrm{d})$, or with grain boundaries, creating a stress or strain concentration. 

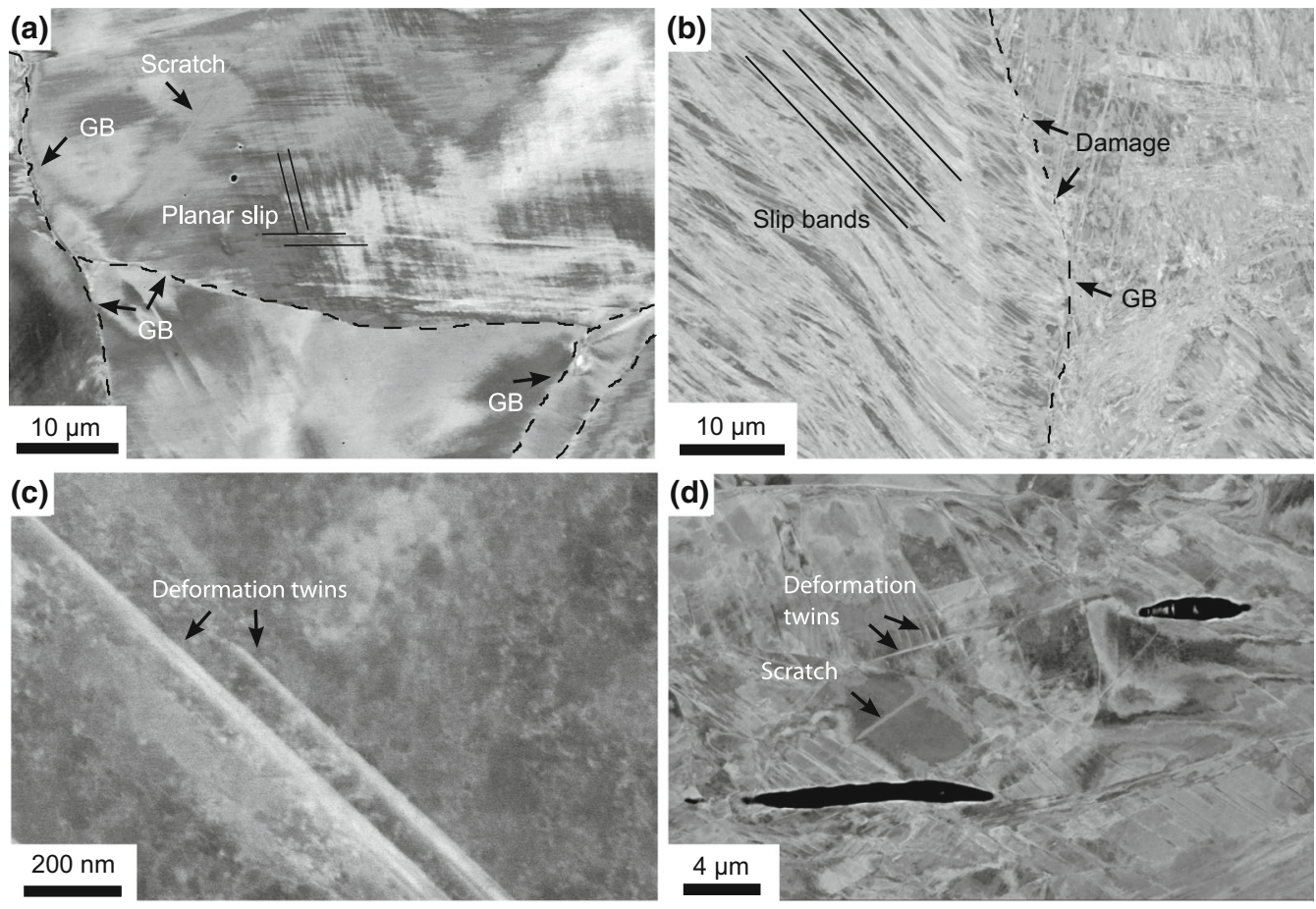

Fig. 5-Deformation mechanisms at room temperature: multi-directional planar slip in AISI 310 (a), several slip bands and damage where the localised bands intersect with the grain boundary (GB) in Alloy $617(b)$, small deformation twins in Sanicro $25(c)$ and multi-directional twinning in AISI $316 \mathrm{~L}(d)$.
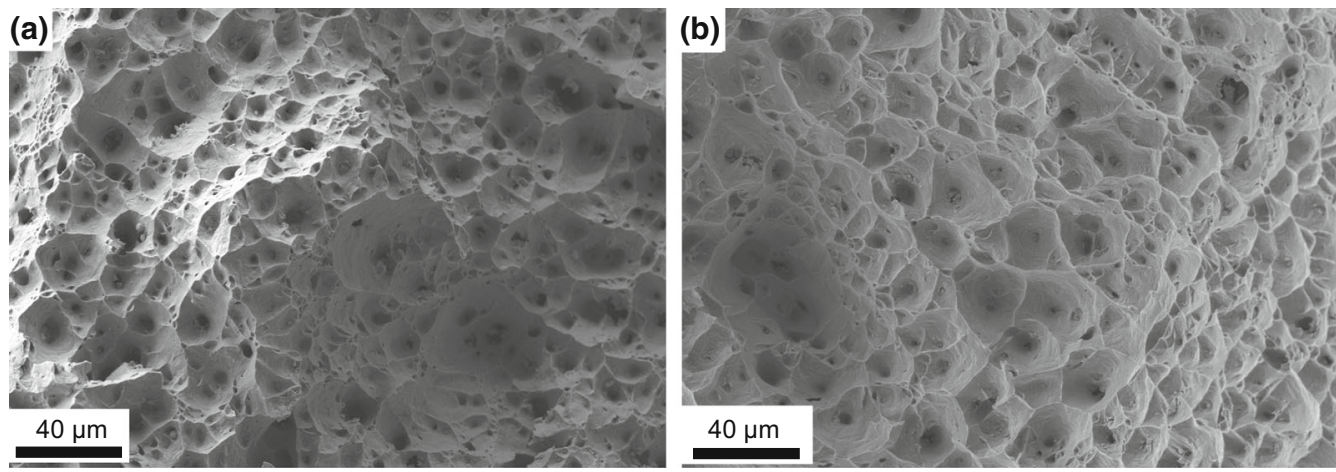

Fig. 6-Ductile fracture surfaces in Sanicro 25 at RT $(a)$ and $873 \mathrm{~K}\left(600{ }^{\circ} \mathrm{C}\right)(b)$.

\section{DISCUSSION}

\section{A. Mechanical Properties at Elevated Temperature}

Austenitic stainless steels and nickel-based alloys are considered to have satisfactory ductility at elevated temperatures but with lower stress-carrying abilities. AISI 316L and AISI 310 showed a drop in ductility already at intermediate temperatures compared to RT. The increase in ductility at $973 \mathrm{~K}\left(700{ }^{\circ} \mathrm{C}\right)$ for AISI 310 should be treated with care since it represents one specimen. Sanicro 25 and Alloy 800HT showed increasing ductility with increasing temperature until it dropped at $923 \mathrm{~K}$ and $873 \mathrm{~K}\left(650{ }^{\circ} \mathrm{C}, 600{ }^{\circ} \mathrm{C}\right)$, respectively, compared to RT. Alloy 617 showed increasing ductility with increasing temperature for all elevated temperatures compared to RT. The damage mechanisms found did not differ considerably between the alloys at elevated temperature, except for damage related to DRX in AISI 316L which is described later, and cannot explain the differences in ductility. All materials in the present study have similar crystallographic structure and are stable at elevated temperatures. Thus, the differences in ductility may depend on chemical composition. In terms of ductility, the alloys rank in order of increasing ductility from: AISI $316 \mathrm{~L} /$ AISI $310 \rightarrow$ Alloy $800 \mathrm{HT} /$ Sanicro $25 \rightarrow$ Alloy 617 . This correlates reasonably well with the alloys' corresponding nickel content. Deformation twinning, which has been 

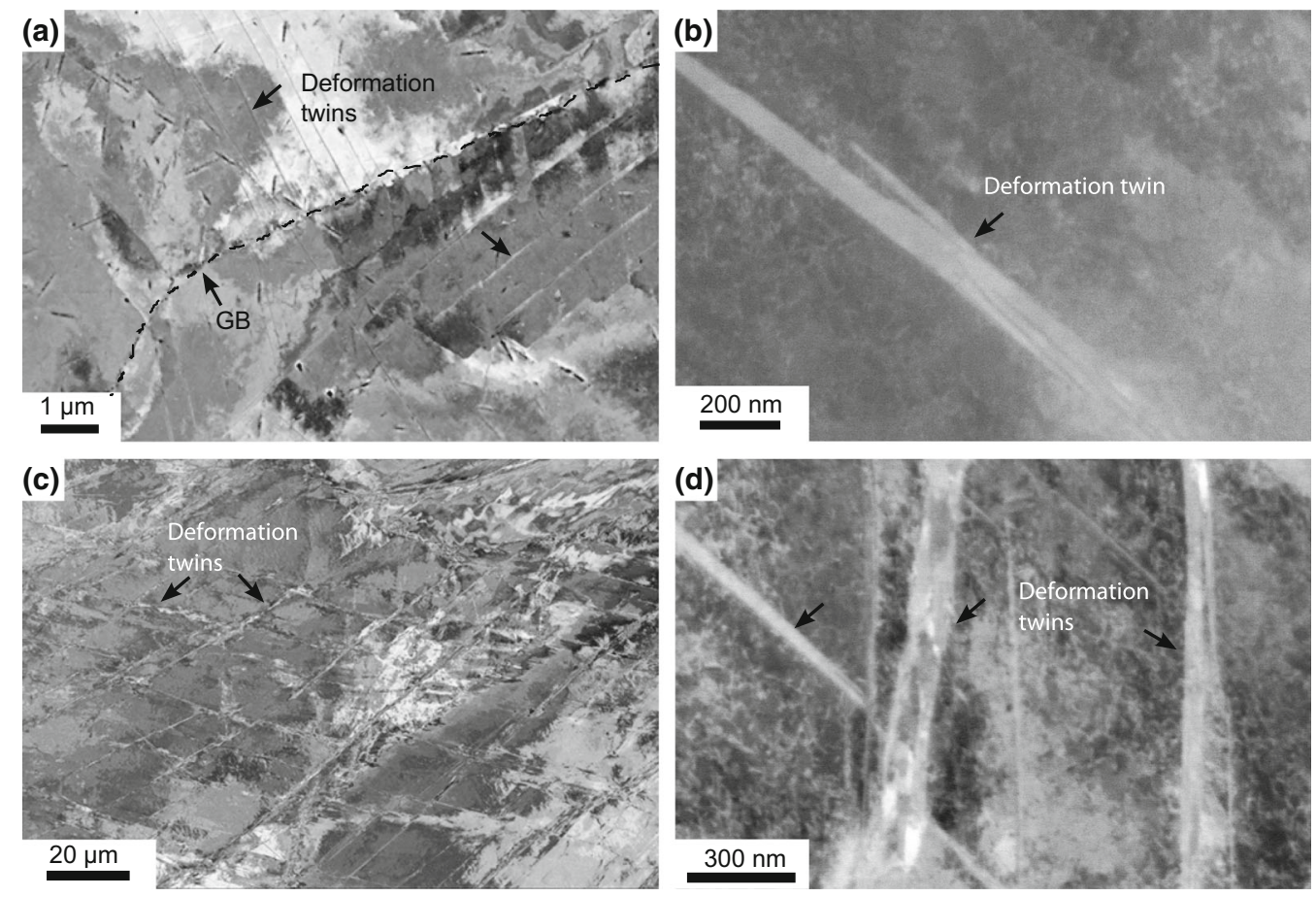

Fig. 7-Deformation twins at $923 \mathrm{~K}\left(650^{\circ} \mathrm{C}\right)$ in AISI $310(a)$, in Sanicro 25 (b), multi-directional twinning in Alloy $800 \mathrm{HT}(c)$ and multi-directional twinning in Alloy 617 (d). GB means grain boundary.

observed at elevated temperature for all alloys, except AISI 316L, may increase ductility by twinning-induced plasticity (TWIP). ${ }^{[30]}$ Low amounts of nickel and the absence of deformation twins partly explain the low ductility of AISI $316 \mathrm{~L}$ at high temperature. However, AISI 310 showed deformation twinning but the ductility decreased as compared to AISI 316L. Hence, deformation twinning cannot alone explain the better ductility of Sanicro 25, Alloy 800HT and Alloy 617 at elevated temperature. The amount of nickel seems to be important for the high-temperature ductility. The marked drop in ductility for Sanicro 25 at $973 \mathrm{~K}\left(700{ }^{\circ} \mathrm{C}\right)$, as seen in Figure 3(c), coincides with a sudden increase in the strain hardening rate, as seen in Figures 3(d) and 13(c). A possible explanation could be a rapid onset of nano-sized precipitate formation at this temperature that was found by Chai et al. ${ }^{[25]}$ To be sure of the existence of nano-sized precipitate that forms rapidly at $973 \mathrm{~K}\left(700{ }^{\circ} \mathrm{C}\right)$ in Sanicro 25, other microstructural analysis techniques are needed; a transmission electron microscopy (TEM) study is suggested for further investigation.

High-temperature strength may be achieved through solid solution hardening and by precipitation at high temperature. Given the chemical composition of the studied alloys, the following strengthening mechanisms may be expected: Precipitates, such as carbonitrides formed from elements such as carbon, nitrogen, niobium and titanium, increase the high-temperature strength. Elements such as molybdenum, tungsten, nitrogen and carbon are responsible for increasing the high-temperature strength by solid solution hardening. Chromium and nickel are known to increase the high-temperature strength ${ }^{[31]}$ and the yield strength in Figure 3(a) and the tensile strength in (b) seem to, to some extent, follow that; when chromium and nickel contents are increased, the high-temperature strength also increases. The yield strengths of Sanicro 25 and Alloy 617 showed slight inclines, whereas AISI 310 showed a steeper incline with increasing temperature; this is attributed the higher amount of solid solution hardening element in Sanicro 25 and Alloy 617 compared to AISI 310. The reason for the higher yield strength with increasing temperature of AISI 310 compared to Alloy $800 \mathrm{HT}$ is believed to be the higher amount of chromium in AISI 310. Despite this, the tensile strengths with increasing temperature are rather the same, which is attributed to the higher amount of precipitation-hardening elements in Alloy 800HT compared to AISI 310. The microstructural analysis techniques used in this study could not reveal the assumed nano-scaled precipitates in Alloy 800HT; a TEM investigation is suggested for further investigation.

To further analyse the stress-strain curves in Figure 2 and the mechanical properties in Figure 3, the strain hardening rate as a function of true plastic strain is plotted in Figure 13. Figure 13(a) shows a comparison of all materials at $873 \mathrm{~K}\left(600{ }^{\circ} \mathrm{C}\right)$ and Figures 13(b) through (d) gives examples of the strain hardening rates for different alloys. Figure 13(a) shows that AISI 316L and AISI 310 had high strain hardening rates initially, but they decreased during plastic deformation, and the 

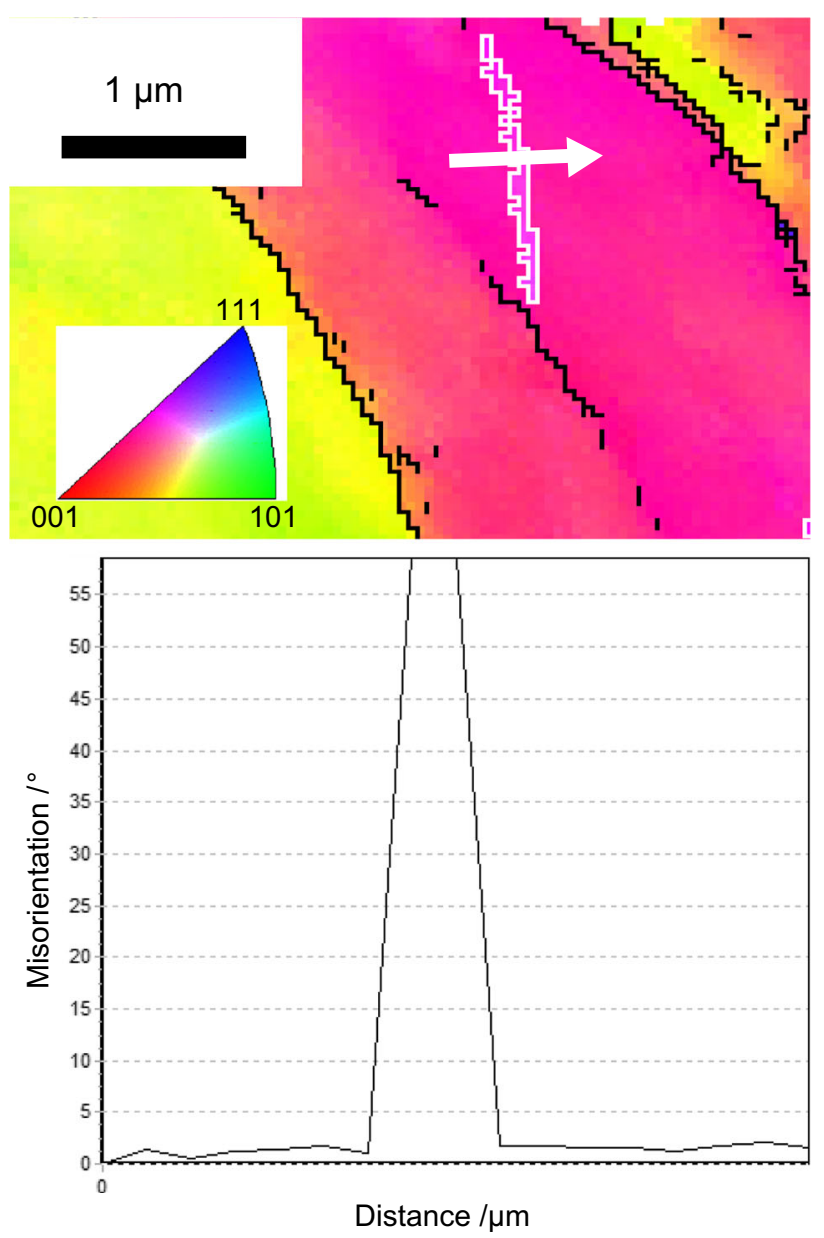

Fig. 8-EBSD analysis displaying orientation and misorientation profile, showing deformation twin with angle 60 deg in Alloy 617 at $923 \mathrm{~K}\left(650{ }^{\circ} \mathrm{C}\right)$. The black lines correspond to grain boundaries with a misorientation larger than $3 \mathrm{deg}$.

other three alloys showed an increasing or nominally flat strain hardening rate during most of the plastic deformation. AISI 316L displayed a decreasing strain hardening rate with increasing true plastic strain at elevated temperatures, as seen in Figure 13(b). The strain hardening rate of AISI 316L was expected be low due to low amounts of solid solution-strenghtening and precipitation-hardening elements. Sanicro 25 first increased in strain hardening rate with increasing strain until a certain true plastic strain level was reached where it, from then on, decreased with further deformation, as shown in Figure 13(c). Alloy 617, as seen in Figure 13(d), showed an increase in strain hardening rate with increasing true plastic strain essentially all the way until fracture at elevated temperatures. The latter two alloys were expected to exhibit a high strain hardening rate due to strengthening mechanisms such as solid solution and precipitation stenghtening. In addition, DSA may increase the strain hardening rate in austenitic stainless steels, but since all alloys showed signs of DSA, even AISI 316L and AISI 310, it cannot be the single reason for the differences. Deformation twinning may also increase the strain hardening rate. ${ }^{[30]}$ However, AISI 310 showed no increase in strain hardening rate during plastic deformation even though it experienced deformation twinning.

In Figure 4, serrated yielding from some of the curves in Figure 2 are presented. Each curve was characterized with a PLC type and the serrated yielding was attributed to DSA. However, serrated yielding from deformation twinning cannot be precluded in the stress-strain curves, especially not at higher strain levels. Deformation twins were often found closer to the fracture surface and are related to higher stress levels which was experienced at high strain levels and closer to fracture. The differences of PLC types seems not to correlate to the differences of mechanical properties in Figure 3 or the active deformation mechanisms.

\section{B. Deformation Mechanisms at Elevated Temperature}

The investigated materials showed planar dislocation-driven deformation at elevated temperatures, as shown in Figures 12(a) and (b). Along the path indicated by arrow (B) in the EBSD map in Figure 14, a more continuous change in misorientation indicates dislocation activity, like planar slip and slip bands.

It is interesting that deformation twins were found at elevated temperatures. Deformation twinning usually does not occur in austenitic stainless steels at the tested temperatures. ${ }^{[24,29,32]}$ Deformation twins as shown in Figures 7 through 10, and the surrounding area, was further studied by EBSD; Figure 14 shows an EBSD map of a few twins in a specimen tested at $923 \mathrm{~K}(650$ $\left.{ }^{\circ} \mathrm{C}\right)$. The crystallographic orientation is displayed according to the colored stereographic triangle. The misorientation profiles in Figure 14 show variations in orientation along the directions marked by arrows (A) and (B). Arrow (A) shows an angular difference of 60 deg, indicating twin boundaries. To further analyse the deformation twining at elevated temperature in austenitic stainless steels and nickel-based alloys, a TEM investigation is suggested.

Deformation in austenitic stainless steel depends on the stacking fault energy (SFE). SFE is influenced by the alloying elements ${ }^{[33]}$ and temperature. ${ }^{[34]}$ Deformation twinning is active in the interval $18<\mathrm{SFE}<45$ $\mathrm{mJ} \mathrm{m}{ }^{-2}{ }^{[35]}$ Under $18 \mathrm{~mJ} \mathrm{~m}^{-2}$, phase transformation from an austenitic phase to a martensitic phase is favored, and above $45 \mathrm{~mJ} \mathrm{~m}^{-2}$, the deformation process is controlled by dislocation glide. ${ }^{[30]}$ The low-alloyed steels can be assumed to have an SFE of $25 \pm$ $5 \mathrm{~mJ} \mathrm{~m}^{-2[36]}$ and the nickel-based alloys an SFE of $45 \pm 5 \mathrm{~mJ} \mathrm{~m}^{-2[37]}$ at RT. Since the SFE increases with increasing temperature ${ }^{[34]}$ dislocation glide should be the favored deformation mechanism, at least in the nickel-based alloys. This was also supported by deformation mechanisms characterization using ECCI and EBSD. However, deformation twinning was active and often found closer to the fracture surface along with dislocation-driven deformation.

Deformation twinning is usually restricted in austenitic stainless steels at elevated temperature due to low stress levels. ${ }^{[24,29,32,38]}$ Lin Peng et al. ${ }^{[39]}$ reported that 

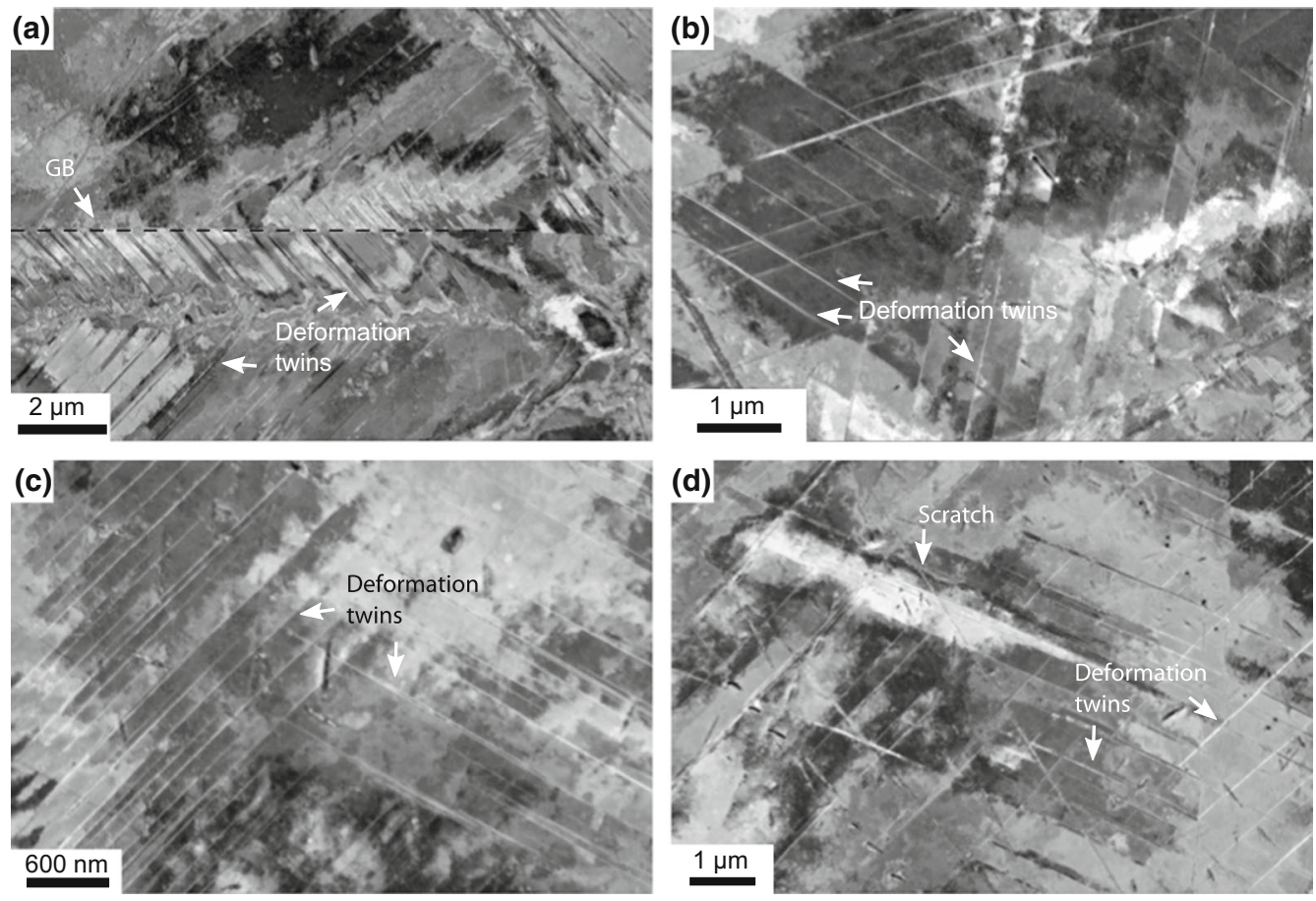

Fig. 9-Deformation twins in AISI 310, at RT (a), $673 \mathrm{~K}\left(400{ }^{\circ} \mathrm{C}\right)(b), 773 \mathrm{~K}\left(500{ }^{\circ} \mathrm{C}\right)(c)$ and $873 \mathrm{~K}\left(600{ }^{\circ} \mathrm{C}\right)(d)$. GB means grain boundary.
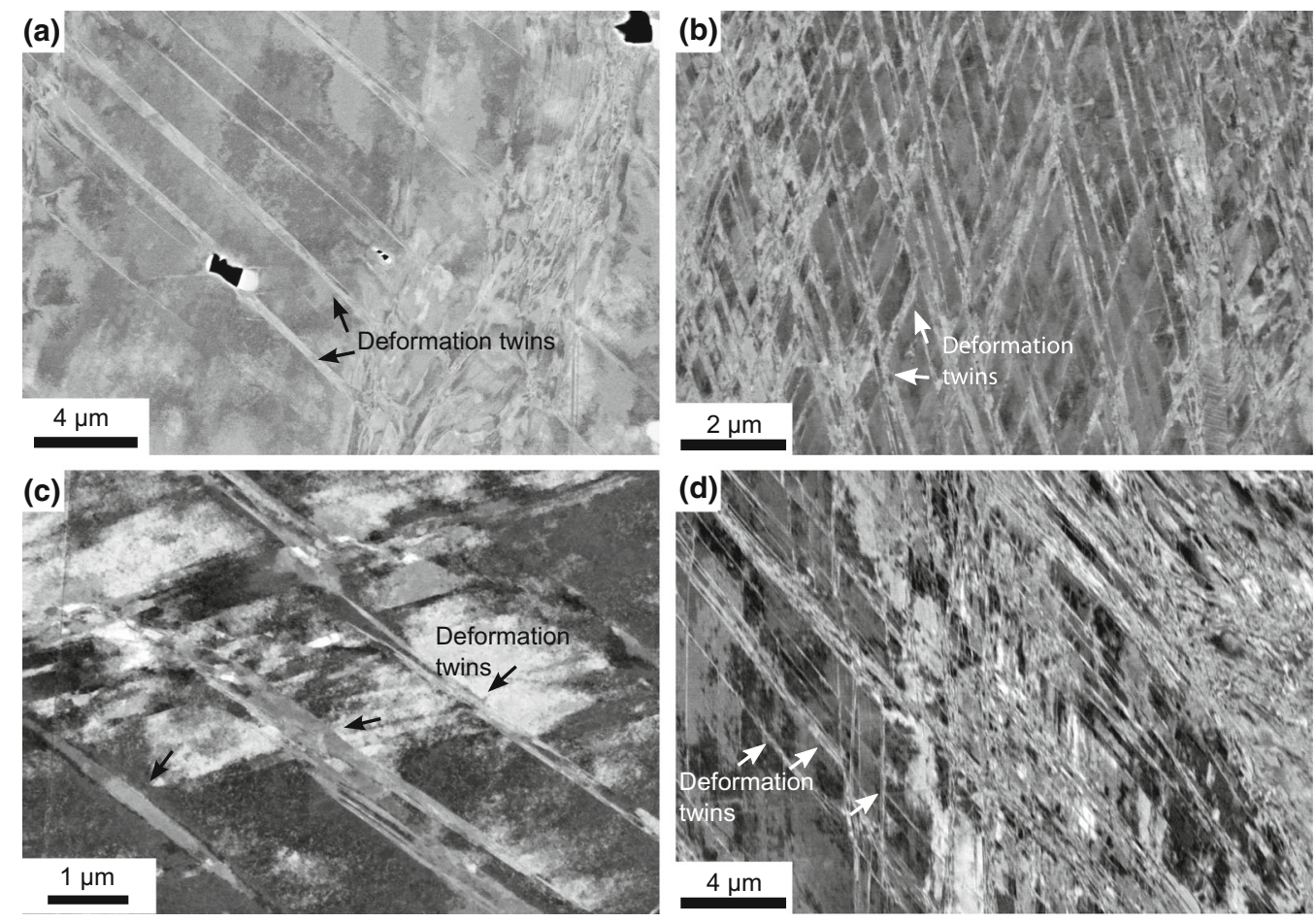

Fig. 10-Formation of deformation twins; at RT in Sanicro $25(a)$ and Alloy $617(b)$, and at $923 \mathrm{~K}\left(650^{\circ} \mathrm{C}\right)$ in Sanicro $25(c)$ and Alloy $617(d)$.

plastic deformation in austenitic stainless steels occurs by planar slip, followed by formation of stacking faults and eventually multi-directional slipping. Only at higher plastic strains does twinning become the dominant deformation mechanism as grains that favor slip become exhausted. ${ }^{[39,40]}$ The deformation twins were found close 

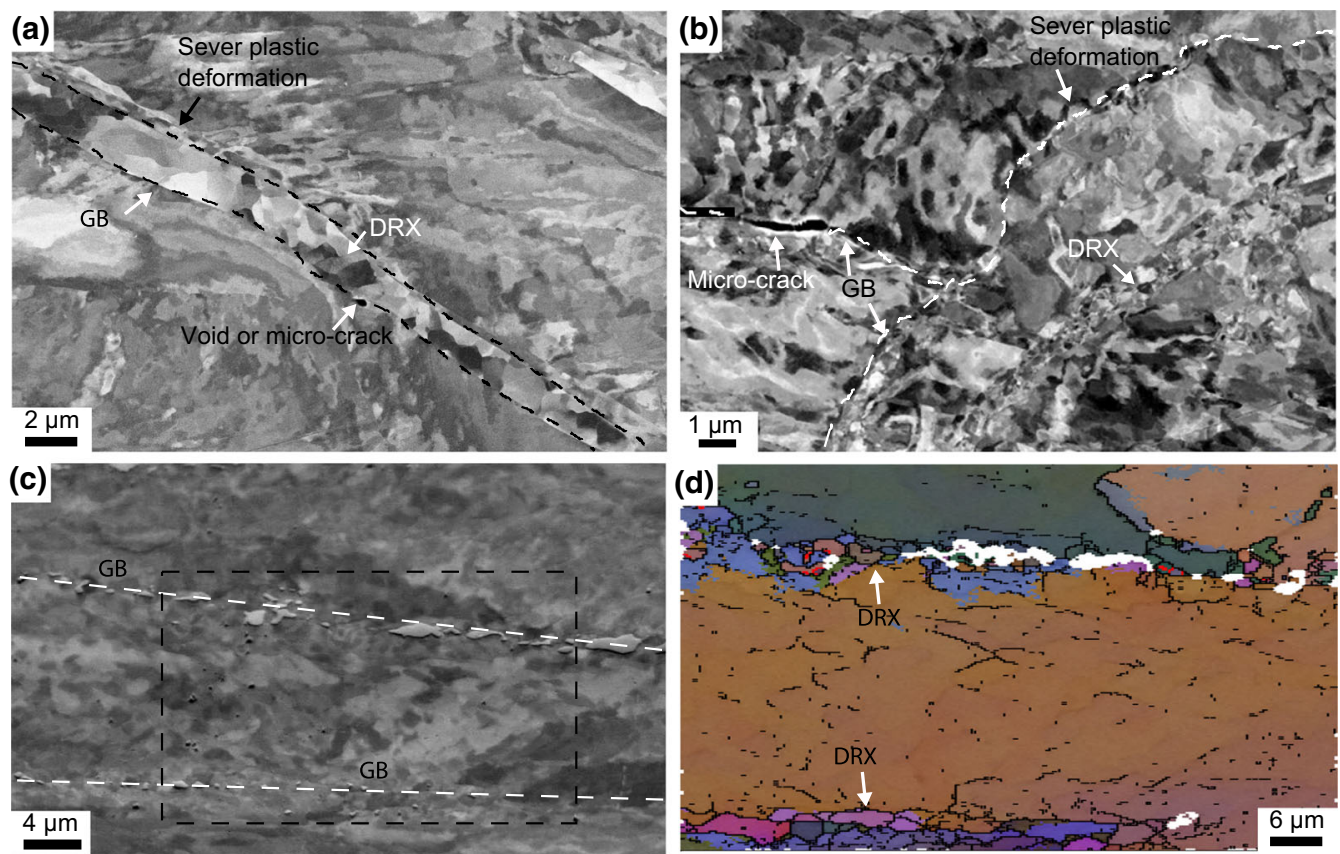

Fig. 11-Dynamic recrystallization (DRX, $a-d)$ in AISI $316 \mathrm{~L}$ at $923 \mathrm{~K}\left(650^{\circ} \mathrm{C}\right)$. (a) and (b) show ECCI micrographs and (c) shows an overview image using secondary electron mode displaying the area of EBSD analysis in (d) with Euler angles displaying recrystallized grains; the black lines correspond to grain boundaries (GB) with a misorientation larger than $3^{\circ}$.
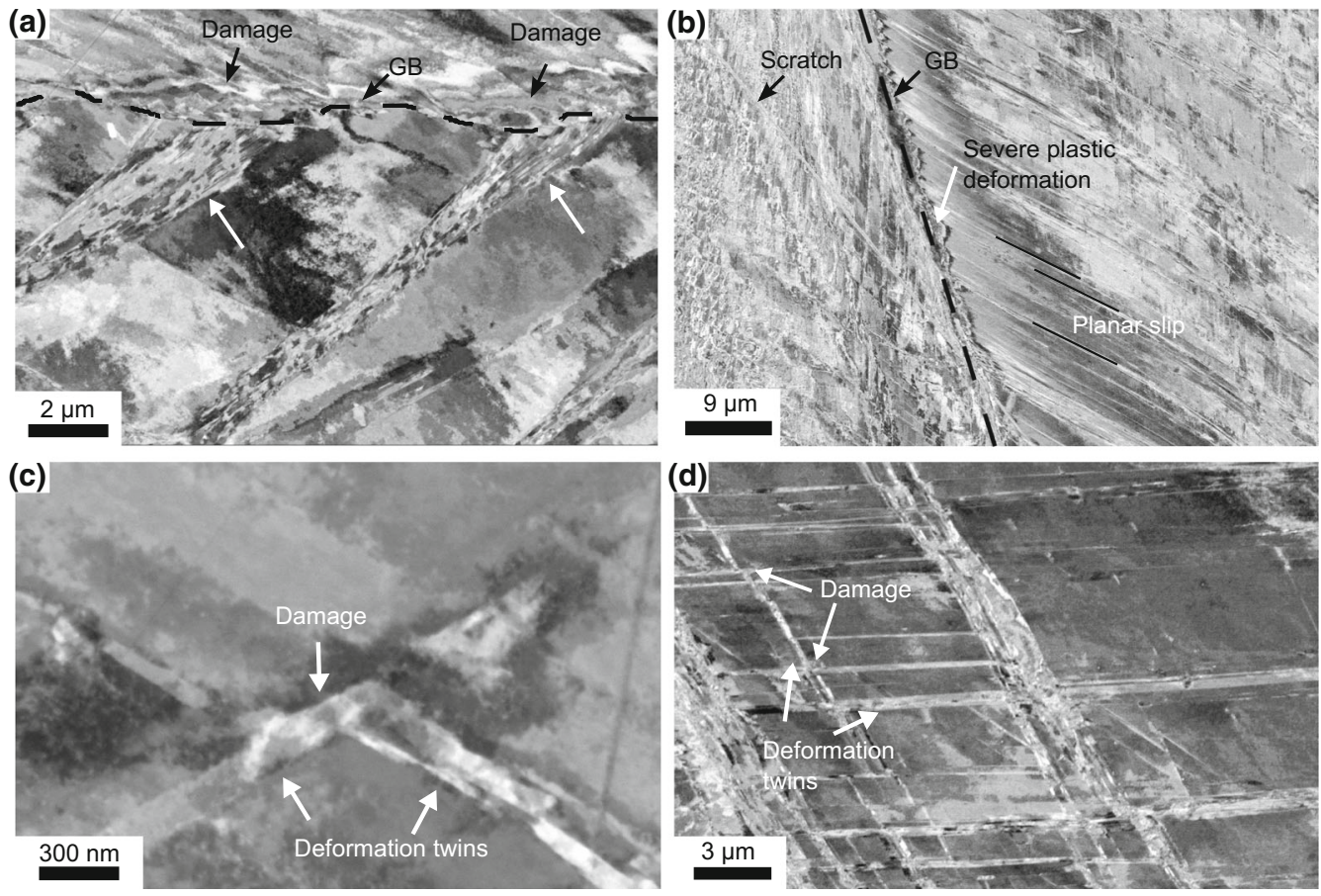

Fig. 12-Damage behavior during the tensile testing: at $923 \mathrm{~K}\left(650{ }^{\circ} \mathrm{C}\right)$, interaction of deformation bands and grain boundaries in Sanicro 25 $(a)$, interaction of planar slip and grain boundaries in Alloy $617(b)$, intersection of two small deformation twins creating a localised strain offset in Sanicro $25(c)$ and intersection of several small twins creating a local strain offset each at $973 \mathrm{~K}\left(700{ }^{\circ} \mathrm{C}\right)$ in Alloy $617(d)$. GB means grain boundary. 


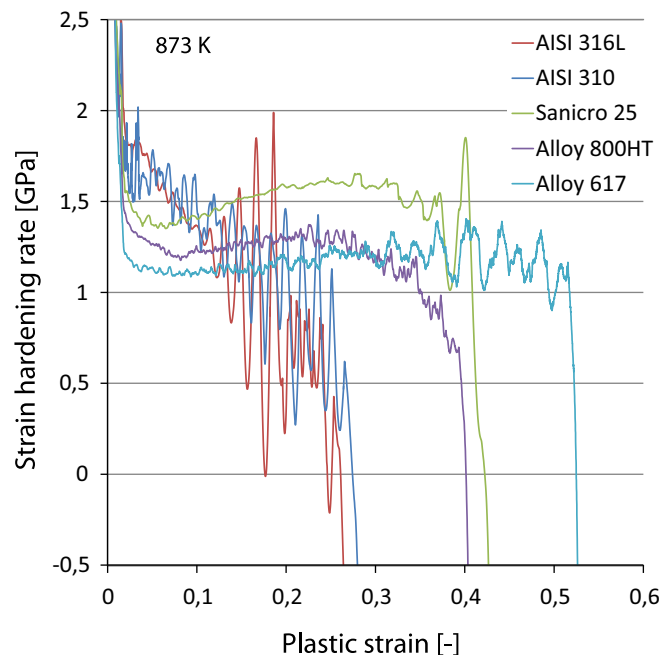

(a)

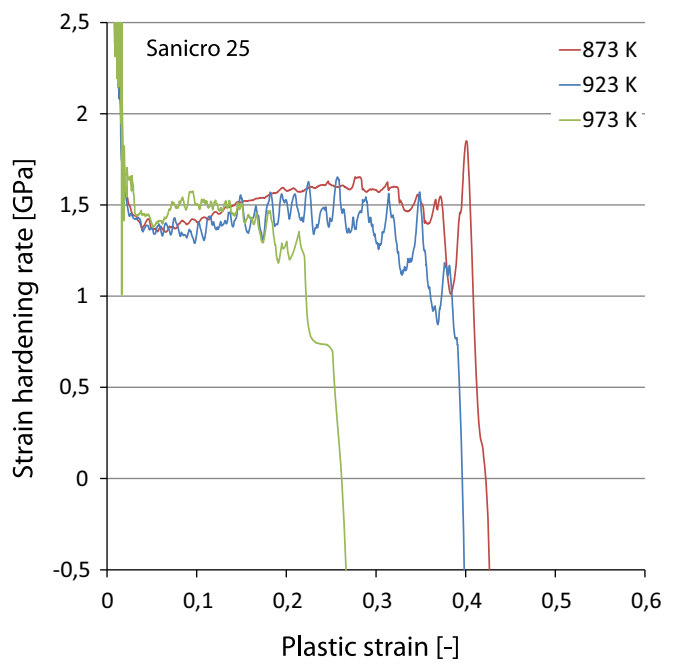

(c)

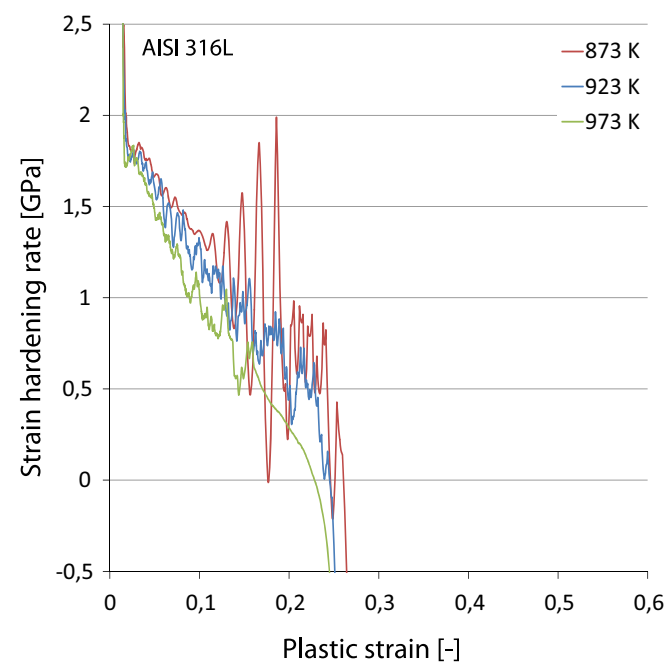

(b)

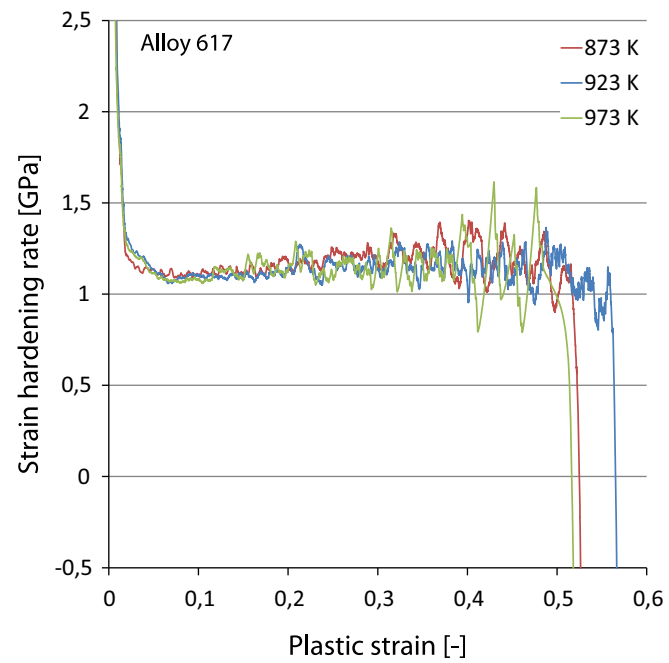

(d)

Fig. 13 - Strain hardening rate and true plastic strain curves: all the materials at $873 \mathrm{~K}\left(600{ }^{\circ} \mathrm{C}\right)(a)$, AISI $316 \mathrm{~L}(b)$, Sanicro $25(c)$ and Alloy 617 (d) at $873 \mathrm{~K}\left(600{ }^{\circ} \mathrm{C}\right)$ to $973 \mathrm{~K}\left(700^{\circ} \mathrm{C}\right)$.

to the fracture surface, which could mean that deformation twins were activated close to the fracture in the deformation process where the stresses were high. The high stress levels needed to activate deformation twinning at elevated temperatures and close to the fracture surface could also be supported by DSA, as proposed by Yapici et al. ${ }^{[32]}$ However, AISI 316L did not show deformation twinning even though it experienced DSA at elevated temperatures; it, instead, showed DRX at elevated temperature and close to the fracture surface. The existence of deformation twins at elevated temperature and high SFE is probably due to preserved high-temperature strength from solid solution and precipitation strengthening supported by DSA. These strengthening mechanisms and the higher stresses close to the fracture in the deformation process, leads to stress levels high enough to activate deformation twinning, in all tested alloys except AISI 316L, which instead showed DRX.
At higher temperatures, when the recovery mechanisms are active, AISI 316L shows damage at grain boundaries, as can be seen in Figures 11(a) and (b). The dislocation density is increasing as the plastic deformation proceeds at the grain boundaries, as severe plastic deformation in Figures 11(a) and (b), suppressing further deformation. If the recovery occurs, i.e. formation of subgrains and recrystallization at the grain boundaries, as shown in Figures 11(c) and (d), they will soften the grain boundary regions and dislocations can again multiply in these regions. If this process is repeated, it will initiate microcracks, as shown in Figures 11(a) and (b), at the grain boundaries which may lead to fracture and lower ductility. ${ }^{[41]}$

\section{CONCLUSIONS}

Tensile testing of five austenitic materials at room temperature and from $673 \mathrm{~K}$ to $973 \mathrm{~K}\left(400{ }^{\circ}\right.$ to $\left.700{ }^{\circ} \mathrm{C}\right)$ 

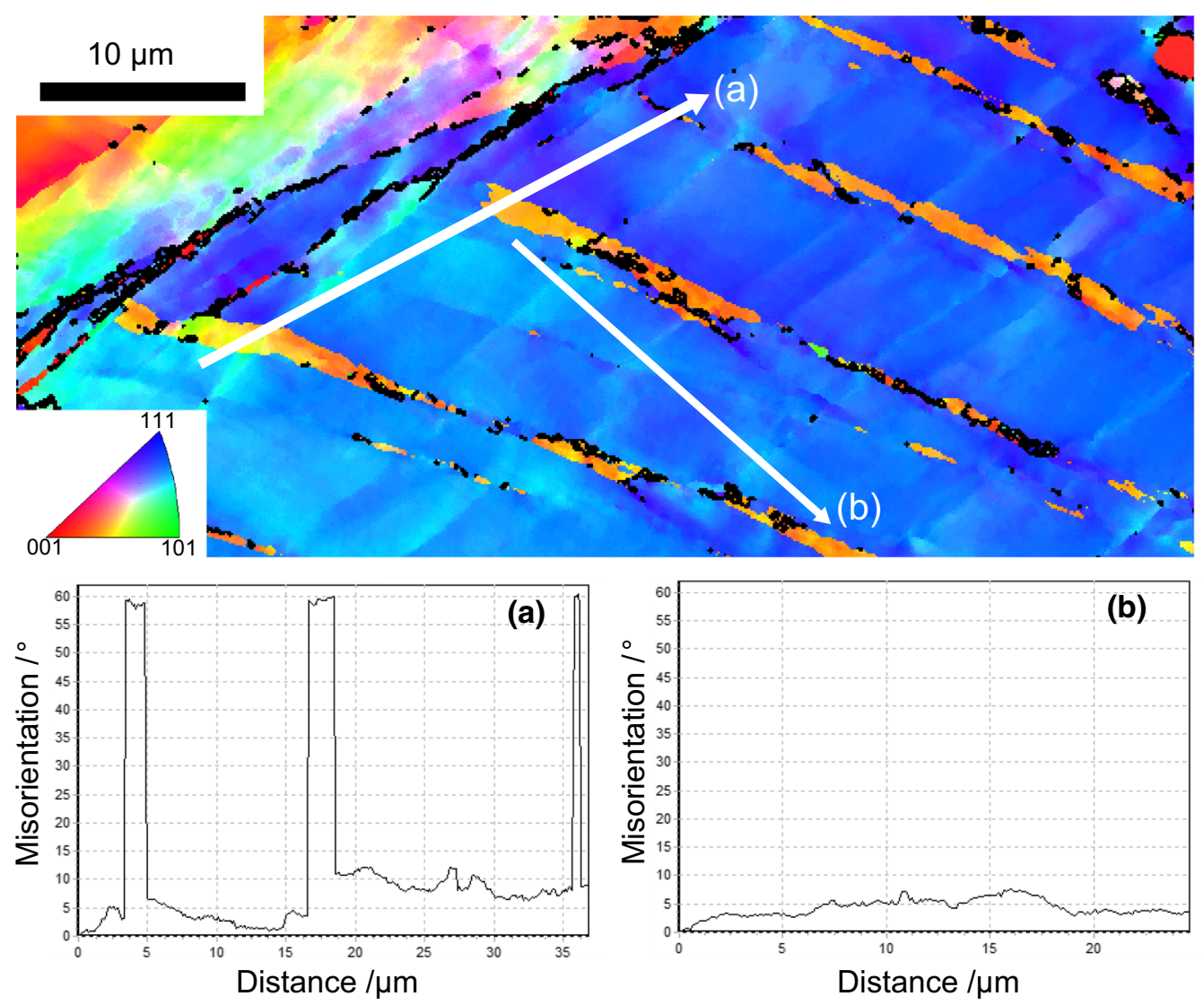

Fig. 14-EBSD analysis displaying orientation and misorientation profiles showing twins with angle of 60 deg $(a)$ and low-angle deformation $(b)$ in Sanicro 25 at $923 \mathrm{~K}\left(650^{\circ} \mathrm{C}\right)$.

was performed. Subsequent study of the microstructure, by ECCI and EBSD, led to the following conclusions: The investigated materials show planar dislocation-driven deformation at elevated temperature, and deformation twinning is an active deformation mechanism even at elevated temperatures up to $973 \mathrm{~K}\left(700^{\circ} \mathrm{C}\right)$ in austenitic stainless steels. Varying influence of temperature on ductility was observed, where a better high-temperature ductility is governed by a higher amount of nickel.

\section{ACKNOWLEDGMENTS}

The present study was financially supported by $A B$ Sandvik Materials Technology in Sweden and the Swedish National Energy Administration through the Research Consortium of Materials Technology for Thermal Energy Processes, Grant No. KME-701. The AFM Strategic Faculty Grant SFO-MAT-LiU\# 2009-00971 at Linköping University is also acknowledged. The assistant work with some of the ECCI pictures by Mr. Jerry Lindqvist and data analysis by Tech. Lic. Viktor Norman is appreciated.

\section{OPEN ACCESS}

This article is distributed under the terms of the Creative Commons Attribution 4.0 International License (http://creativecommons.org/licenses/by/4.0/), which permits unrestricted use, distribution, and reproduction in any medium, provided you give appropriate credit to the original author(s) and the source, provide a link to the Creative Commons license, and indicate if changes were made.

\section{REFERENCES}

1. P. Viklund, A. Hjörnhede, P. Henderson, A. Stålenheim R. Pettersson: Fuel Process. Technol., 2013, vol. 105, pp. 106-12.

2. L. Trygg and S. Amiri: Appl. Energy, 2007, vol. 84, pp. 1319-37.

3. A.K.M. Sadrul Islama and M. Ahiduzzaman: AIP Conf. Proc., 2012, vol. 1440 , pp. $23-32$.

4. R. Viswanathan and W. Bakker: J. Mater. Eng. Perform., 2001, vol. 10 , pp. $81-95$.

5. J. Pettersson, H. Asteman, J.-E. Svensson, and L.-G. Johansson: Oxid. Met., 2005, vol. 64, pp. 23-41.

6. T. Sourmail: Mater. Sci. Technol., 2001, vol. 17, pp. 1-14.

7. F.B. Pickering: Stainless Steels, 1985, vol. 84, pp. 2-28.

8. V. Vodárek: Mater. Sci. Eng., A, 2011, vol. 528, pp. 4232-38.

9. R.D. Doherty, D.A. Hughes, F.J. Humphreys, J.J. Jonas, D.J. Jensen, M.E. Kassner, W.E. King, T.R. McNelley, H.J. McQueen, and A.D. Rollett: Mater. Sci. Eng., A, 1997, vol. 238, pp. 219-74. 
10. S.-G. Hong and S.-B. Lee: J. Nucl. Mater., 2005, vol. 340, pp. $307-14$.

11. S.L. Mannan, K.G. Samuel, and P. Rodriguez: Mater. Sci. Eng., 1985, vol. 68 , pp. 143-49.

12. G.R. Stewart and J.J. Jonas: IISIJ Int., 2004, vol. 44, pp. 1263-72.

13. I. Nikulin and R. Kaibyshev: Mater. Sci. Eng., A, 2011, vol. 528, pp. $1340-47$.

14. L.H. de Almeida, P.R.O. Emygdio, and I. Le May: Scr. Metall. Mater., 1994, vol. 31, pp. 505-10.

15. L.H. de Almeida, I. Le May, and P.R.O. Emygdio: Mater. Charact., 1998, vol. 41, pp. 137-50.

16. W. Karlsen, M. Ivanchenko, U. Ehrnstén, Y. Yagodzinskyy, and H. Hänninen: J. Nucl. Mater., 2009, vol. 359, pp. 156-61.

17. M. Hörnqvist and B. Karlsson: Mater. Sci. Technol., 2006, vol. 22, pp. 213-22.

18. A. Van Den Beukel: Acta Metall., 1980, vol. 28, pp. 965-69.

19. R.A. Mulford and U.F. Kocks: Acta Metall., 1979, vol. 27, pp. $1125-34$.

20. G.V.P. Reddy, R. Sandhya, M. Valsan, and K.B.S. Rao: Mater. Sci. Technol., 2010, vol. 26, pp. 1384-92.

21. G.V.P. Reddy, R. Sandhya, K.B.S. Rao, and S. Sankaran: Procedia Eng., 2010, vol. 2, pp. 2181-88.

22. M.C. Cai, L.S. Niu, T. Yu, H.J. Shi, and X.F. Ma: Mater. Sci. Eng., A, 2010, vol. 527, pp. 5175-80.

23. M. Ivanchenko, PhD-thesis, Dynamic Strain Aging of Austenitic Stainless Steels and Ni-Base Alloys, Aalto University, 2010.

24. M.A. Meyers, O. Vhringer, and V.A. Lubarda: Acta Mater., 2001, vol. 49 , pp. $4025-39$.

25. G. Chai, M. Boström, M. Olaison, and U. Forsberga: Procedia Eng., 2013, vol. 55, pp. 232-39.
26. M. Lundberg, J. Saarimäki, J.J. Moverare, and M. Calmunger: Mater. Charact., 2017, vol. 124, pp. 215-22.

27. I. Gutierrez-Urrutia, S. Zaefferer, and D. Raabe: Scr. Mater., 2009, vol. 61, pp. 737-40.

28. S. Johansson, J. Moverare, and R. Peng: Pract Metallogr, 2013, vol. 50, pp. 810-20.

29. J.W. Simmons: Mater. Sci. Eng., A, 1996, vol. 207, pp. 159-69.

30. J. Lu, L. Hultman, E Holmström, K.H. Antonsson, M. Grehk, W. Li, L. Vitos, and A. Golpayegani: Acta Mater., 2016, vol. 111, pp. 39-46.

31. J.R. Davis: Stainless Steels, ASM International, Materials Park, 1994.

32. G.G. Yapici, I. Karaman, Z.P. Luo, H.J. Maier, and Y.I. Chumlyakov: J. Mater. Res., 2004, vol. 19, pp. 2268-78.

33. S. Lu, Q.-M. Hub, B. Johansson, and L. Vitos: Acta Mater., 2011, vol. 59 , pp. 5728-34.

34. S. Curtze, V.-T. Kuokkala, A. Oikari, J. Talonen, and H. Hänninen: Acta Mater., 2011, vol. 59, pp. 1068-76.

35. S. Curtze and V.-T. Kuokkala: Acta Mater., 2010, vol. 58, pp. $5129-41$.

36. X. Feaugas and C. Gaudin: Mater. Sci. Eng., A, 2001, vols. 309-301, pp. 382-85.

37. D.M. Symons: Metall. Mater. Trans. A, 1997, vol. 28, pp. 655-63.

38. X. Wu, X. Pan, J.C. Mabon, M. Li, and J.F. Stubbins: Nucl. Mater., 2006, vol. 356, pp. 70-77.

39. R.L. Peng, M. Odén, Y.D. Wang, and S. Johansson: Mater. Sci. Eng., A, 2002, vol. 334, pp. 215-22.

40. L. Xiong, Z.S. You, and L. Lu: Scr. Mater., 2017, vol. 127, pp. 173-77.

41. Y. Ohmori and Y. Meaehara: Mater. Sci. Technol., 1986, vol. 2, pp. 595-602. 